\title{
TRACING OF THE LIKELY ENTRY AND DISPERSAL PATHWAYS OF THREE RECENT PEST AND DISEASE INCURSIONS INTO NEW ZEALAND
}

\author{
K.J. FROUD, T.T. ASHCROFT, D. GUNAWARDANA, \\ M.S. BULLIANS, L.B. KUMARASINGHE, H.O. PEARSON, \\ B.S.M. LEBAS and F.M. OCHOA-CORONA
}
National Plant Pest Reference Laboratory, Ministry of Agriculture and Forestry, PO Box 2095, Auckland
Corresponding author:froudk@maf.govt.nz

\begin{abstract}
Tracing new pests has two aims, to determine the entry pathway and to determine the potential for dispersal and spread. Tracing entry pathways enables the Ministry of Agriculture and Forestry to target risk goods for inspection and enhance Import Health Standards. Impatiens necrotic spot virus (INSV) was identified from freesias grown from seed in a Christchurch nursery in August 2003. INSV is not seed transmissible and survey work and tracing discovered a link at two sites between impatiens imported as tissue culture from the USA. However, this link was not conclusive, since the same impatiens tested negative when traced to a third site. The nest of a tropical fire ant (Solenopsis geminata), a potential health and environment pest, was discovered in June 2003 adjacent to a container yard drainage culvert at Mt Maunganui. Historical interception records, site characteristics and diagnostic evaluation indicate the most likely entry pathway was direct establishment from a shipping container from the Pacific Islands. White-spotted longicorn beetle, Anoplophora chinensis, a potential forestry pest was discovered at an industrial property in Tauranga in July 2003. Tracing determined the entry pathway as wooden reels from China. Eight out of ten reels were traced and fumigated or destroyed.
\end{abstract}

\section{NEW PLANT VIRUS AND VIRUS-LIKE DISEASE RECORDS IN NEW ZEALAND AND INTERCEPTIONS IN POST-ENTRY QUARANTINE: UPDATE 2002-2003}

\author{
F.M. OCHOA-CORONA, B.S.M. LEBAS, D.R. ELLIOTT, Z. TANG and \\ B.J.R. ALEXANDER
}

\section{National Plant Pest Reference Laboratory, Ministry of Agriculture and Forestry, PO Box 2095, Auckland 1015, New Zealand \\ Corresponding author: Francisco.Ochoa-Corona@maf.govt.nz}

The National Plant Pest Reference Laboratory (NPPRL) continuously monitors New Zealand's plant health status and develops and provides diagnostic and advisory services to the Crown. Detection and identification methodologies used include mechanical transmission to herbaceous indicators, electron microscopy, ELISA, PCR and genome sequencing. Viruses newly reported for New Zealand during the last two years include Cycas necrotic stunt virus (CNSV), Impatiens necrotic spot virus (INSV), Soil-borne wheat mosaic virus (SBWMV), a suspect foveavirus and an unidentified potexvirus. The presence of a new-to-New Zealand phytoplasma ("poinsettia phytoplasma") was also confirmed. New plant virus and viroid host associations were reported in New Zealand for Arabis mosaic virus (ArMV), Potato spindle tuber viroid (PSTVd), Strawberry latent ringspot virus (SLRSV) and Turnip mosaic virus (TuMV). Successful interceptions of High plains virus (HPV) and Carnation cryptic virus 1 and 2 (CCV 1 and 2) were made for plants in post-entry quarantine. 